\title{
Requirements for Building Thermal Conditions under Emergency Operations in Cold Climates
}

\author{
AlexanderM. Zhivov, ${ }^{1 *}$ William B. Rose, ${ }^{2}$ RaymondE. Patenaude, ${ }^{3}$ and W. Jon Williams ${ }^{4}$ \\ ${ }^{1}$ U.S. Army Engineer R\&D Center, Champaign, IL (USA) \\ ${ }^{2}$ William B. Rose \& Associates, Inc. Urbana, IL (USA) \\ ${ }^{3}$ Holmes Engineering Group LLC, St. Petersburg, FL (USA) \\ ${ }^{4}$ National Personal Protective Technology Laboratory NIOSH/CDC, Pittsburg, Pa (USA)
}

\begin{abstract}
This paper provides recommendations on thermal and moisture parameters in different types of buildings under emergency operation in cold/arctic climates. We consider three scenarios under normal operating conditions: occupied, temporarily unoccupied, and long-term unoccupied. These thermal parameters are necessary to: (1) perform required work safely and efficiently, (2) support building processes, and (3) support long-term integrity of the building under emergency conditions (i.e., interruption of fuel, steam, hot water, and electrical service that interrupts building space conditioning). Under emergency conditions, requirements of thermal parameters for different categories of buildings may change. Mission critical areas can be conditioned to levels that support the agility of personnel who perform critical operations, but not to optimal comfort levels. Critical process requirements are given priority. This paper was developed for military applications, based on research performed under the International Ene rgy Agency's Energy in Buildings and Communities Program, Annex 73; under the Department of Defense Environmental Security Technology Certification Program project EW18-D1-5281, "Technologies Integration to Achieve Resilient, Low-Energy Military Installations," and under the Office of the Deputy Assistant Secretary of the Army project "Thermal Energy Systems Resiliency for Army Installations located in cold climates." Results are applicable to similar public and private sector buildings.
\end{abstract}

\section{Introduction}

During an emergency situation, requirements of thermal parameters for different categories of buildings or even parts of the building may change. When the operation of normal heating, cooling, and humidity control systems is limited or una vailable, mission critica la reas can be conditioned to the level of themal parameters required to support the agility of personnel who perform mission critical operations, but not to the level of their optimal com fort conditions. Beyond these threshold (habitable) levels, effective execution of criticalmissions is not possible and mission operators have to be moved into a different location. These threshold limits of thermal parameters may be in a broader range compared to those required for themal comfort, but not to exceed levels of heat and cold stress thresholds. However, special process requirements (e.g., with IT and communication equipment, critical ho spital spaces, etc.) should be given a priority if they are more stringent. Broader ranges of air temperatures and humidity levels in building spaces surrounding mission critical a reas may be used, but they need to be limited to prevent excessive thermal losses/ga ins and moisture transfer through wa lls and apertures not designed with thermal, and air/vapor barriers. Finally, noncritical standalone buildings can be hibernated, but necessary mea sures should be taken, and the thermal environment should be maintained when possible to prevent significant damage to these build ings before they can be returned back to their normal operation.

\section{Normal (blue sky) operating conditions}

Under normal opera ting conditions, for any given building, factors like building envelope insulation and a irtightness, ventila tion rates, thermostat setpoints, plug loads, and lighting levels have a significant impact on building energy consumption and cost. These factors affect a building's energy performance in a ny climate, whether arctic or hot/humid.

It is important that engineers and operations and maintenance $(\mathrm{O} \& \mathrm{M})$ personnel design for and use a pprop riate rates and setpoints to main tain these thermal conditions, which provide occupant comfort, health, and productivity, and which minimize energy usage in normal operation conditions a nd make thermal systems more resilient during emergency operation. Setting these rates and setpoints can be as much of an art as a science, but there are a number of standard references that are used to help in the operation of the building. The following references provide guidance on the suggested values.

\footnotetext{
* Corresponding author: Alexander.M.Zhivov@usace.army.mil
} 
Thermal requirements include criteria for themal comfort and health, process needs, and criteria for preventing the freezing of wa ter pipes, growth of mold and mildew, and other damage to the building materials or furnishings. Under normal operating conditions, code compliant buildings are presumed to be free of mold and mildew problems; if these conditions do occur, they become matters for O\&M intervention.

Thermal comfort and health criteria primarily involve the temperature and humidity conditions in the building. Too high a temperature means that occupants are uncomfortably hot. Too low a temperature means that occupants are uncomfortably cold. The wrong humidity (rooms typically do not have humidistats) means that occupants feel damp or sweaty or too dry. Thermal comfort is defined by ASHRAE Standard 55 [1]. When the space is unoccupied during a short period of time (e.g., few days), the room thermostat should be set back to $55^{\circ} \mathrm{F}\left(12.7^{\circ} \mathrm{C}\right)$. In spaces unoccupied for an extended period of time (e.g., weeks), temperature should be controlled at $40^{\circ} \mathrm{F}\left(5^{\circ} \mathrm{C}\right)$.

Process related criteria include temperature and humidity needed to perform the process housed in the building (e.g., spaces with IT and Communications equipment, critical hospital a reas, industrial processes [pa inting, printing, etc.]). While new design guidance for computer systems indicates a much higher tolerance for high temperatures than previously thought, there are specialized electronic and laboratory equipment that have fairly tight temperature and humidity requirements for protection from damage caused by electrostatic discharge. Archival storage of important documents also involves rela tively tight tolerances for temperature and humidity.

IT Facilities. Many mission critical facilities or dedica ted spaceswithin these facilities (e.g., emergency operation centers, Sensitive Compartmented Information Facilities [SCIFs], Network Operations Centers [NOCs], Network Enterprise Centers [NECs]) house computer systems and a ssociated components, such as telecommunications and storage systems. Environmental requirements for spaces with IT and Communications equipment may vary depending on type of equipment or manufacturer. According to ASHRAE [2], there are six standard classes of themal requirements.

Class A1. Typica lly, a datacom facility with tightly controlled environmental parameters (dew point [DP], temperature, and relative humidity $[\mathrm{RH}]$ ) and mission critical operations, including those housing servers and data storage.

Class A2/A3/A4. Typically, the types of products typically designed for use in a $\mathrm{n}$ information technology space with some control of environmental parameters (DP, temperature, and RH), are volume servers, storage products, personal computers, and workstations. Among these three classes, A2 has the narrowest temperature and moisture requirements and $\mathrm{A} 4$ has the widest environmental requirements. (Classes A3 and A4 do not have special requirements to be considered.)

Class B. Typically an office, home or transportable environment with a little control of environmental parameters (temperature only), including personal computers, workstations, and printers.

Class C. Typically, a point of sale or light industrial environment with weather protection.

In a dition to four classes of requirements for IT and Communications equipment facilities discussed above, there are also requirements for Network EquipmentBuilding System (NEBS) offices housing switches, routers, and similar equipment with some control of environmental parameters (DP, temperature, and RH). Table 1 lists the recommended and allowable conditions for Cla ss A1, Class A2, and NEBS environments.

Table 1. Recommended and allowable conditions for Classes A1-A2, and NEBS environments.

\begin{tabular}{|c|c|c|c|c|}
\hline \multirow[b]{2}{*}{ Conditions } & \multicolumn{2}{|c|}{ ClassA1/ClassA2 [3] } & \multicolumn{2}{|c|}{ NEBS [2] } \\
\hline & $\begin{array}{c}\text { Allowable } \\
\text { level }\end{array}$ & $\begin{array}{c}\text { Recommended } \\
\text { level }\end{array}$ & $\begin{array}{c}\text { Allowable } \\
\text { level }\end{array}$ & $\begin{array}{c}\text { Recommended } \\
\text { level }\end{array}$ \\
\hline $\begin{array}{l}\text { Temperature } \\
\text { control range }\end{array}$ & & \multirow{3}{*}{$\begin{array}{c}64^{\circ} \mathrm{F}-80^{\circ} \mathrm{F} \\
\left(11^{\circ} \mathrm{C}-27^{\circ} \mathrm{C}\right)\end{array}$} & \multirow{3}{*}{$\begin{array}{l}41^{\circ} \mathrm{F}- \\
104^{\circ} \mathrm{F} \\
\left(5^{\circ} \mathrm{C}-\right. \\
\left.40{ }^{\circ} \mathrm{C}\right)\end{array}$} & \multirow{3}{*}{$\begin{array}{c}65^{\circ} \mathrm{F}-80^{\circ} \mathrm{F} \\
\left(18^{\circ} \mathrm{C}-27^{\circ} \mathrm{C}\right)\end{array}$} \\
\hline $\mathrm{A} 1$ & $\begin{array}{c}51^{\circ} \mathrm{F}-89^{\circ} \mathrm{F} \\
\left(11^{\circ} \mathrm{C}-32^{\circ} \mathrm{C}\right)\end{array}$ & & & \\
\hline$A 2$ & $\begin{array}{c}51^{\circ} \mathrm{F}-91^{\circ} \mathrm{F} \\
\left(11^{\circ} \mathrm{C}-33^{\circ} \mathrm{C}\right)\end{array}$ & & & \\
\hline $\begin{array}{l}\text { Maximum } \\
\text { temperature } \\
\text { rate of change }\end{array}$ & $\begin{array}{c}9^{\circ} \mathrm{F} / \mathrm{hr} \\
\left(31^{\circ} \mathrm{F} / \mathrm{hr}\right)^{1} \\
\left(5^{\circ} \mathrm{C} / \mathrm{hr}\right. \\
\left.\left[2^{\circ} \mathrm{C} / \mathrm{hr}\right]\right)\end{array}$ & & $\begin{array}{l}2.9^{\circ} \mathrm{F} / \mathrm{hr} \\
\left(1.6^{\circ} \mathrm{C} / \mathrm{hr}\right)\end{array}$ & \\
\hline $\begin{array}{l}\text { RH control } \\
\text { range }\end{array}$ & & \multirow{3}{*}{$\begin{array}{c}15^{\circ} \mathrm{F}-51^{\circ} \mathrm{F} \mathrm{DP} \\
\left(-1{ }^{\circ} \mathrm{C}-11^{\circ} \mathrm{C}\right) \mathrm{DP} \\
\text { and } 60 \% \mathrm{RH}\end{array}$} & \multirow{3}{*}{$\begin{array}{c}5 \%-85 \% \\
82{ }^{\circ} \mathrm{F} \\
\left(28^{\circ} \mathrm{C}\right) \\
\text { Max DP }\end{array}$} & \multirow{3}{*}{$\operatorname{Max} 55 \%$} \\
\hline A1 & $\begin{array}{c}10^{\circ} \mathrm{F}\left(-11^{\circ} \mathrm{C}\right) \\
\text { DP and } 8 \% \mathrm{RH} \\
\text { to } 62^{\circ} \mathrm{F}\left(11^{\circ} \mathrm{C}\right. \\
\text { DPP and } \\
80 \% \mathrm{RH}\end{array}$ & & & \\
\hline $\mathrm{A} 2$ & $\begin{array}{l}10^{\circ} \mathrm{F}\left(-11^{\circ} \mathrm{C}\right) \\
\text { DP and } 8 \% \mathrm{RH} \\
\text { to } 69^{\circ} \mathrm{F}\left(21^{\circ} \mathrm{C}\right) \\
\text { DP and } 80 \% \text { RH }\end{array}$ & & & \\
\hline $\begin{array}{l}{ }^{1} 9^{\circ} \mathrm{F} / \mathrm{hr} \text { - forta } \\
9^{\circ} \mathrm{F} \text { in any } 15 \mathrm{r}\end{array}$ & $\begin{array}{l}\text { pe storage, } 31^{\circ} \mathrm{F} / \\
\text { nin period of time }\end{array}$ & / hrfor all other IT e & quipment ar & nd not morethan \\
\hline
\end{tabular}

Health Care Facilities. Health Care Facilities represent another group of mission critical facilities. Per NFPA 99, Hea lth Care Fa cilities [3] include, but are not limited to, hospitals, nursing homes, limited care facilities, clinics, medical and dental offices, and a mbulatory health care centers. This definition a pplies to normal, regular opera tions and does not pertain to facilities during declared local or national disasters. Patient Care Spaces in Health Care Facilities are described using the following four categories:

- Category 1 Space. Space in which failure of equipment or a system is likely to ca use major injury or dea th of patients, sta ff, or visitors.

- Category 2 Space. Space in which failure of equipment or a system is likely to cause minor injury to pa tients, staff, or visitors. 
- Category 3 Space. Space in which the failure of equipment or a system is not likely to cause injury to patients, staff, or visitors but can cause discomfort.

- Category 4 Space. Space in which failure of equipment or a system is not likely to have a physical impact on patient care.

Examples of requirements to thermal environment in spaces included in categories 1 and 2 are listed in Table 2.

Table 2. Thermal environment requirements for selected spaces in medical facilities [4].

\begin{tabular}{|l|c|c|c|}
\hline Space & $\mathbf{T}^{\circ} \mathbf{F}$ & $\mathbf{T}^{\circ} \mathbf{C}$ & $\mathbf{R H ,} \%$ \\
\hline Class B and C operating rooms & $68-75$ & $20-24$ & 30 to 60 \\
\hline $\begin{array}{l}\text { Operating/surgical cystoscopy } \\
\text { rooms }\end{array}$ & $68-75$ & $20-24$ & 30 to 60 \\
\hline Delivery room & $68-75$ & $20-24$ & 30 to 60 \\
\hline $\begin{array}{l}\text { Critical and intensive care } \\
\text { unit) }\end{array}$ & $70-75$ & $21-24$ & 30 to 60 \\
\hline $\begin{array}{l}\text { Radiology } \\
\text { Class A operating/procedure } \\
\text { room }\end{array}$ & $70-75$ & $21-24$ & 40 to 60 \\
\hline $\begin{array}{l}\text { X-ray (surgery/critical care and } \\
\text { catheterization) }\end{array}$ & $70-75$ & $21-24$ & Max 60 \\
\hline Pharmacy & $70-72$ & $21-22$ & Max 60 \\
\hline
\end{tabular}

The environmental conditions (temperature and humidity) maintained in indoor spaces determine not only the comfort of the occupants of those spaces but also the long-term condition of the building itself. Historically, only the dry bulb temperature (DBT) of indoor spaces was controlled to achieve comfortable indoor conditions for the occupants. Little a ttention was given to control of moisture/humidity in the spaces. As a result, many existing Army buildings have exhibited mold/mildew problems.

Arctic buildings. Eliminating mold growth from surfa ces of buildings requires year-round control of both the DBT and the DP temperature (or air RH) in the indoor spaces in hot/humid climates. In arctic climates, even those humidified up to $30 \%$ RH indoors should not exhibit mold problems given the low temperature and vapor pressure outdoors. Preliminary transient hygrothermal analysis (done as a part of preparation of the Guide [5]) of common arctic building wall and roof assemblies shows no risk of mold growth except for atypical assemblies. The use of low-permeance insulating materials in wall and roof assemblies presents strong a ssurance of good moisture performance.

Temperature may be set back in arctic buildings during short-and long-term periods, provided measures a re taken to prevent pipe bursting. See below. This may require keeping the interior of the building heated to $50{ }^{\circ} \mathrm{F}\left(10^{\circ} \mathrm{C}\right)$. Setting back temperature does not present a mold risk in arctic climates. Of course, outdoor a ir to the building should be shut off during unoccupied periods.
It is important that designers and O\&M personnel design and maintain the building and heating, ventilating, and air-conditioning (HVAC) systems to satisfy all three categories of requirements. In most of cases, thermal comfort requirements sa tisfy the process. Preventing moisture-related problems requires special attention to the design and building operation. Energy conservation should not be achieved at expense of health, occupant's wellbeing, and building susta inability. Certain stra tegies and technologies can minimize or eliminate premium energy use.

\section{Emergency (black sky) operating conditions}

Depending on the emergency situation, the objective for any mission critical a rea of the given building is to maintain mission critical operations as long as it is necessary or technically possible. As for other, noncritical building areas and standalone buildings, the objective is to minimize the damage to the asset. It is a ssumed that building processes will be kept operational only in mission critical areas and non-mission critical activities will be discontinued. In the mission critical a rea s/buildings, operations will continue, and processes will require people with critical skills and thought processes. While under normal circumstances, building environmental controls are designed and operated to create a thermoneutral environment conducive to optimal employee thermal environment discussed in the section under blue sky operating condition. However, should the building environmental controls fail for any reason, the thermal environment may change in such a way as to no longer be optimal for workers needing their critical skills to perform their jobs. The section below describes threshold indoor environmental conditions beyond which human physical and mental skills can no longer be maintained.

Under black sky operations, efforts should be made to maintain thermal environment to prevent significant damage to both mission critical and non-mission critical buildings before they can be returned back to their normal operation. This may include reduction of ventila tion requirements; control of maximum humidity levels using available technologies with minimum fuel consumption; allowing maximum daylight; keeping plug loads on and lowering lighting levels; in cooling constraint conditions, use window shades to minimize solar gains, reduce plug loads, and keep lighting at a minimum level.

Threshold Conditions for Human Environment. While cold and hot stress environmental conditions are well defined for jobs performed outdoors $[6,7,8]$, there is not much information a vailable for such conditions when jobsare performed indoors. This section addresses the potential thermal "inflection point" when the person can no longer physiologically and behaviorally compensate for the thermal stress while on the job based on the following a ssumptions and considerations: 
1. The building environmental control systems fail and cannot be restored over a period of hours to days.

2. The occupants of the building must stay in that building to perform theirjobs (i.e., cannot lea ve to move to more comfortable conditions).

3. The building occupants do nothave access to clothing that can provide anything more than minimal protection against either cold or hot conditions (at most a clothing insula tion of Clo $\leq 1.0)$.

4. The building occupants a re generally healthy with the normal physiological responses to deviations in environmentalconditions.

5. The workers remain inside the building and perform minimal physical work (nearly at rest, the energy generated inside the body due to metabolic activity $1.2-1.5 \mathrm{met}$ ). At this minimal workload, the metabolic heat produced will be minimal (slightly above that produced a trest).

6. Factors such a sconvection and direct ra diation from the sun will be considered negligible.

7. Air movement in the building occupied zone is below $0.7 \mathrm{ft} / \mathrm{min}(0.2 \mathrm{~m}) / \mathrm{min}$ and, a s such, there is little convectiveheat transfer.

8. Building is lit using either fluorescent, or LED lighting, which results in a negligible ra diant heat from lighting fixtures.

9. The building environmental conditions will be affected as a result of the function of the HVAC system in an indoor setting, and that the environmental stressors a re the dry a ir temperature (dry bulb or $\mathrm{T}_{\mathrm{db}}$ ) and humidity or wet bulb temperature $\left(\mathrm{T}_{\mathrm{wb}}\right)$ with other environmental factors such a s a ir velocity and ra diant heat being negligible.

Humans have evolved the ability to maintain a stable internal (core) temperature $\left(\mathrm{T}_{\text {core }}\right)$ in the face of environmental thermal extremes through physiological, biophysical, and behavioral means. Maintenance of a stable $\mathrm{T}_{\text {core }}$ involves a tight balance between heat gain and heat loss to the environment during exposure to either cold or hot environments. A detailed discussion of the physiological and behavioral responses to themal extremes is beyond the scope of the present work. However, note that, although there are strong physiological and behavioral mechanisms for maintaining $T_{\text {core, }}$, these can be overcome under severe thermal stress - especially if that thermal burden is prolonged.

The physiological responses, and the rate and magnitude that they occur, will depend on the rate and magnitude of the change in the environmental temperature and, to a greater (hot temperature) or lesser (cold temperature) extent, the RH of the air. The rate of change in the building environment in which environmental controls have failed will depend on the insulating properties of the building, i.e., the rate and magnitude of the change in temperature and $\mathrm{RH}$. The physiological responses will also depend to a large extent on the degree of personal insulation (clothing) the worker must wear to protect against the decrease in environmental temperature.

A "normal" core body temperature, $\mathrm{T}_{\text {core, }}$ is considered to be $98.6^{\circ} \mathrm{F}\left(37^{\circ} \mathrm{C}\right)$. It is at this temperature that optimal physiological function occurs. The physiological consequences (i.e., $\Delta \mathrm{T}_{\text {core }}$ ) from a decrease or an increase in environmental temperature can be severe. If the physiological responses to environmental temperature changes (and the ability to maintain $T_{\text {core }}$ ) are unsuccessful, then $T_{\text {core }}$ will change (either decrease or increase); if the change is large enough, then normal function will be com promised. For example, a $\mathrm{T}_{\text {core }}$ of $96.8^{\circ} \mathrm{F}\left(37^{\circ} \mathrm{C}\right)$ is considered the onset of hypothermia. At $\mathrm{T}_{\text {core }}<95^{\circ} \mathrm{F}\left(35^{\circ} \mathrm{C}\right)$ one becomes symptomatic (see Table 3 ). The physiological responses to environmental heat are an increase in blood flow to the skin and sweating, which serve to transfer heat to the environment. These responses are more successful in maintaining $\mathrm{T}_{\text {core }}$ in an environment with low humidity and a high capacity to accept moisture (Tdb). If there is an increase in Twb (increased RH), then sweat evaporation is reduced and a potential for an increa se in $\mathrm{T}_{\text {core }}$ occurs. Hyperthermia occurs when $\mathrm{T}_{\text {core }}$ is $>100.4^{\circ} \mathrm{F}\left(>38^{\circ} \mathrm{C}\right)$. This is normally tolerable, and the person can continue to perform well. However, as the $\mathrm{T}_{\text {core }}$ increa ses beyond $100.4^{\circ} \mathrm{F}\left(38^{\circ} \mathrm{C}\right)$, the ability to perform work begins to be compromised. Physiologica1/psychological signs and symptoms of hyperthermia are listed below:

- Extremediscomfort

- Numbness (tactile sensitivity, manual dexterity decreases)

- Shivering

- Skin va soconstriction(bla nching)

- Cold that becomes a distraction

- Muscle stiffness

- Cognitive changes (confusion, a pathy, loss of attention, reduced memory ca pacity, etc.)

- Loss of sensory information (blurred vision)

- Cardiovascular effects

- Loss of consciousness.

It is important to understand that probably the first line of defense against cold is clothing that creates an insulative layer that protects the humans from cold environments. With this strategy, a human being may perform activities in a cold $\left(41^{\circ} \mathrm{F}\left[5^{\circ} \mathrm{C}\right]\right)$ environment but be "exposed" to a microenvironment (the layer ofair that exists between the surface of the skin and the inner surface of the clothing) that is the equivalent to a mild temperature $\left(\sim 71.60^{\circ} \mathrm{F} \quad\left[\sim 22^{\circ} \mathrm{C}\right]\right)$. Nevertheless, working in cold environments has demonstrable effects on humans even if wearing relatively warm clothing. Early studies of the thermal effects on human performance $[9,10]$ focused on the frequency of industrial accidents that could be related to ambient temperature. The rate of industrial accidents could be described as a " $U$ " curve in that the lowest frequency of a ccidents occurred at a temperature of $\sim 68^{\circ} \mathrm{F}\left(\sim 20^{\circ} \mathrm{C}\right)$ and increased as the ambient temperature either decreased or increased from $68^{\circ} \mathrm{F}\left(20^{\circ} \mathrm{C}\right)$. The 
frequency of industrial accidents increased to a lmost $140 \%$ as the temperature decreased from $68^{\circ} \mathrm{F}$ to $\sim 50{ }^{\circ} \mathrm{F}$ $\left(20^{\circ} \mathrm{C}\right.$ to $\sim 10^{\circ} \mathrm{C}$ ) indicating cold temperatures had a significant effect on worker a bility to perform their tasks sa fely. The decline in manual dexterity begins at a $\mathrm{T}_{\mathrm{s}}$ of $53.1^{\circ} \mathrm{F}-60.1^{\circ} \mathrm{F}\left(12^{\circ} \mathrm{C}-16^{\circ} \mathrm{C}\right)$. Tactile sensitivity declines steeply below $46^{\circ} \mathrm{F}\left(8^{\circ} \mathrm{C}\right)$. This may severely limit the use of computers and other equipment that requires the use of both manual dexterity and tactile sensitivity. Similar loss of cognitive function and manual dexterity occurred in hot environments as well (starting at a $\mathrm{T}_{\text {core }}$ of $>98.1^{\circ} \mathrm{F}\left(>39^{\circ} \mathrm{C}\right)$.

Thermal discomfort often becomes a distraction to the person experiencing it and, hence can affect performance or the so-called "time of task" or time spent not working but addressing the thermal discomfort. The degree of distraction is affected by whether the person can leave the environment or somehow change the environment (changing a thermostat setting) to improve the thermal comfort. If the person has no control over an uncomfortable thermal environment, the degree of distraction or time off task will increa se. The distraction occurs as the result of a physiological change, e.g., decrease or increase in $T_{s k}$, which then results in the focus of attention on that change ra ther than on the task before them. Distraction is also modulated by motivation such that a more strongly motivated person may be less distracted by cold stimulus that a less motivated person exposed to the same stimulus. In addition, if the person exposed to a cold stimulus perceives that they have no control over the environment and the consequence of not performing the work is high enough, then the cold environment will be less distracting from the necessary work. As can be seen from the previous discussion, the issue of distraction on cognition and job performance is complex.

Therefore, in emergency situations, reduction of indoor air temperature in spaces with mission critical buildings operation below $60.8^{\circ} \mathrm{F}\left(16^{\circ} \mathrm{C}\right)$ [8] and increase in Wet Bulb Globe Temperature (WBGT) above $87.8^{\circ} \mathrm{F}\left(31^{\circ} \mathrm{C}[6]\right)$ is not recommended since it will impair performance ofmission operators.

Arctic Buildings under Emergency Conditions. Mold growth. Arctic climates present low risk of mold growth on building surfaces. Mold does not grow at low temperatures. In a ddition, a retic outdoor vapor pressures a re very low, so without humidification, indoor RH will be quite low. Mold growth depends greatly on the sensitivity of a surface to growth, and surfaces made of organic materials such as wood products and paper facings present the sole possibilities in arctic climates - not metal, concrete, or masonry. Preliminary modeling studies, using humidification at $30 \%$, in U.S. DoE climate zones 6, 7, and 8, show surface RH remaining at $65 \%$ or below, while mold require surfa ce $\mathrm{RH}$ a bove $85 \%$ in most cases.

Aside from water problems associated with roof or plumbing leaks, the grea test risk of mold growth may be from cold thermal bridges in humidified buildings. Thermal bridges may be identified using infrared (IR) thermography. Typically, in a well-insulated building, the coldest surface facing the interior will be the window surface. It is unlikely that interior temperatures at thermal bridges will be lower than the window surface temperature. Consequently, in an arctic building, the risk of interior mold growth is negligible in a building that shows no window condensation, and the presence of window condensation indicates the importance of lowering the indoor humidification.

In arctic climates, if building climate control is suspended in the short or long term, then mold growth is unlikely to occur. Normally, downward drift of temperature will occur with suspension of the operation of the air handler. This means that the indoor a ir temperature will decline as a function of the outdoor air temperature, the thermal insulation, the a irtightness of the building, and the heat storage by the contents of the building. Also, during a heating period, the outdoor absolute humidity will be lower than the indoor a bsolute humidity, so it will drift downward at a rate govemed prima rily by the airtightness of the envelope.

Under most conditions, the downward drift of absolute humidity will be much more rapid than the downward drift of DBT, and as a consequence, the indoor RH will be low during the drift period. The downward drift of absolute humidity is considered rapid because, with each air change, assuming full mixing the absolute humidity difference between indoors and out, is halved. Absolute humidity equilibrium with outdoors would be a chieved in a matter of hours. The downward drift of temperature would be relatively slow given the low heat content of air, the thermal resistance in the envelope, and the heat storage in interior materials. It would be measured typically in days.

Modeling has provided preliminary estimates of the temperature decay rate of arctic buildings in case of a utility interruption. For a building with a verage thermal resistance of R-20 (all sides), with an a ir tightness of $0.25 \mathrm{cfm}\left(0.0001 \mathrm{~m}^{3} / \mathrm{s}\right)$ per $75 \mathrm{sq} \mathrm{ft}\left(7 \mathrm{~m}^{2}\right)$, and which contains, in envelope and contents, $100 \mathrm{lb} / \mathrm{sq} \mathrm{ft}$ $\left(0.05 \mathrm{~kg} / \mathrm{cm}^{2}\right)$ of envelope, the decay half-life is approximately 1 week. By doubling the thermal resistance or the mass of contents, or by halving the air leakage, the half-life is doubled to 2 weeks. By halving the thermal resistance or the content mass, or by doubling the air leakage measure, the half-life of temperature decay is reduced to 3 to 4 days. Of course, different parts of the building will perform differently.

Pipe Burst Protection. In cold and arctic climates, hydronic heating systems typically use a glycol/water solution as the heating system fluid [11]. To reduce the risk of freezing of wa ter pipes or wet sprinkler systems, pipes should be located in interior walls or plumbing chases. Pipes in exterior walls should be avoided. However, in the emergency situation when heat supply to the building is interrupted, the indoor a ir temperature can drop significantly. Research at the University of Illinois [12] has illustrated the mechanism by which water pipes burst when surrounded by cold temperatures. Cold air temperatures cause the temperature of water in pipes to decline. Water temperature may decline below $32^{\circ} \mathrm{F}\left(0^{\circ} \mathrm{C}\right)$, often to $25^{\circ} \mathrm{F}\left(-4^{\circ} \mathrm{C}\right)$. With continued cold temperatures, ice nucleates in the water, raising the temperature of the 
two-phase mix to $32^{\circ} \mathrm{F}\left(0^{\circ} \mathrm{C}\right)$. With continued cold temperatures, ice begins to grow on the pipe wall, growing inward; the rate of ice growth depends on several factors such as air temperature, pipe themal conductivity, wa ter circulation, and effect of the air film surrounding the pipe. Through this entire process, before the formation of blockage, the pipe system is not put at risk, and with rising a ir temperatures the system will recover to the original condition with no ill effects.

If the ice grows inward to the point of blockage, then water pressure effects become important. The blockage can grow along the length of the pipe and act like a piston. Piston action toward the water source will genera lly have no ill effect, in the absence of a backflow preventer. But piston a ction toward the remaining liquid water confined downstream will cause the water pressure to rise. Pipe rupture or fitting failure will occur once the wa ter pressure reaches a sufficiently high level.

There a re several means to prevent pipe bursting due to freezing:

1. Avoid subzero a ir temperatures at the pipe.

2. Drain the water from the pipe system. Compressed a ir may be used for systems that do not drain entirely by gra vity.

3. Provide pressure relief a t any at-risk portion of the pipe system. A single pressure relief valve is usually sufficient to protect a clustered fixture group. A ballcock a ssembly in a typical toilet serves a s a pressure relief device (which explains the grea ter likelihood of hot water rupture during freeze events).

4. Provide a ir expansion (using wa ter hammer a rresters for example) to protect piping systems where the slight water leakage from pressure relief valves is undesirable, such a s in wet fire

suppression systems.

It is particularly important to a void individual sites of particularly cold temperature along the pipe length, as these a re preferred sites for blockage to initiate. Such sites will occur at interruptions in pipe insulation (often at fittings such as elbows) and at air leaks in the envelope, where moving air can reduce the air film thermal resistance.

\section{Thermal requirements for unoccupied spaces}

Requirements for temperatures and $\mathrm{RH}$ discussed above are developed for occupied spaces (Table 3 ). Many buildings are not occupied at night or on weekends. Some military facilities including barracks, a dministrative buildings, and dining facilities may be unoccupied for an extended period of time due to training and deployment. So, one energy conservation stra tegy may be to set back temperatures for heating or set up for cooling. One source of guidance on set back or set up temperatures is ANSI/ASHRAE/IESNA Standard 90.1 Energy Standard for Buildings Except Low-Rise Residential Buildings [13]. This Standard does not regulate thermostat setbacks or setups, but it does regula te the capabilities of thermostats installed in buildings. Section 6.4.3.3.2 of Standard 90.1, Setback Controls, requires that heating systems in all parts of the United States outside of Miami, FL and the tropical islands (that is, climate zones 2-8) must have a capability to be set back to $55^{\circ} \mathrm{F}\left(13^{\circ} \mathrm{C}\right)$. Heating systems in zone 1 are assumed to have minimal usage and therefore no need of setbacks. Cooling systems in hot dry areas (zones $1 \mathrm{~b}, 2 \mathrm{~b}$, and $3 \mathrm{~b}$ ) must have the capability to be set up to $90^{\circ} \mathrm{F}\left(32^{\circ} \mathrm{C}\right)$. However, cooling systems in hot and humid climates (zones 1a, 2a, and $3 \mathrm{a}$ ) a re not required to have cooling setbacks due to potential for moisture problems. It is wasteful to cool facilities left unoccupied for a n extended period of time, which are located in hot and humid climates. Significant energy savings can be achieved without damage to building materials and furnishings if a combination of measures related to the building envelope and HVAC maintain the requirements for all the air inside the building.

Table 3. Requirements of DBT and RH for occupied and unoccupied facilities to reduce the risk of moisture-related problems.

\begin{tabular}{|c|c|c|c|}
\hline & DP (Setpoint) & $\begin{array}{c}\text { Maximum } \\
\text { Dry Bulb } \\
\text { Temp } \\
\text { Occupancy/Use }\end{array}$ & $\begin{array}{c}\text { Minimum } \\
\text { Dry Bulb } \\
\text { Temp } \\
\text { (Setpoint) }\end{array}$ \\
(Setpoint)
\end{tabular}

\section{Conclusion}

Requirements for thermal environmental condition in buildings a re set to a chieve the following purposes:

- To perform the required work in a building in a safe and efficientmanner,

- To support processes housed in the building, and

- To provide conditions required for a long-term integrity of the building and building materials.

Buildings are designed to meet these three sets of requirements in normal (blue sky) operating condition. Thermal comfort requirements are defined by ASHRAE Standard 55. Different processes housed in the building (e.g., spaces with IT and Communications equipment, critical hospital areas, industrial process [painting, printing, etc.]) may have broader or narrower ranges for a ir temperature and $\mathrm{RH}$, than those for human comfort. In normal operation conditions, environmental requirements based on sustainability of building envelope assemblies and furnishings a re not a limiting factor given that the building envelope a ir barrier and vapor protection are designed to a void mold growth and water accumulation within the building a ssembly (for cold and arctic climates requirements to the building envelopesee [5]). 
During an emergency situation (black sky), requirements of thermal parameters for different ca tegories of buildings or even parts of the building may change. When normal heating, cooling, and humidity control systems operation is limited or not available, mission critical a reas can be conditioned to the level of thermal parameters required for supporting a gility of personnel performing mission critical operations, but not to the level of their optimal comfort conditions. Beyond these threshold (habitable) levels, effective execution of a critical mission is not possible and mission operators have to be moved into a different location. These threshold limits of thermal parameters may be in a broader range compared to that required for thermal comfort, but not to exceed levels of heat and cold stress thresholds: in a heating mode, a ir temperature in spaces with mission critical operations should be maintained above $60.8^{\circ} \mathrm{F}\left(16^{\circ} \mathrm{C}\right)$ [8], and in a cooling mode, the Wet Bulb Global Temperature should be below $87.8^{\circ} \mathrm{F}\left(31^{\circ} \mathrm{C}[6]\right)$.

Special process requirements (e.g., with IT and communication equipment, critical hospital spaces, etc.) should be given a priority if they are more stringent. Broa der ranges of a ir temperatures and humidity levels in building spaces surrounding mission critical areas may be used, but they need to be limited to prevent excessive thermal losses/gains and moisture transfer through walls and apertures not designed with thermal and a ir/vapor barriers.

In arctic climates, building envelope assemblies are not a limiting factor regarding how indoor climate needs to be maintained during short- or long-term outages of indoor climate control, unless water piping cannot be dra ined or otherwise protected a gainst freezing.

In cases where utility supply is interrupted and the building a ir handler is disabled, the indoor temperature will decay to the outdoor temperature. The rate of decay has been field tested and modeled $[14,15]$; results show that the time it takes for indoor a ir temperature to reach a threshold (habitable) level or a building susta inability level will range from a few hours to several days depending on thermal resistance, a irtightness, and the mass of the building envelope and contents in the building.

To avoid water damage to building materials and furnishings in cold and arctic climates, DBT should exceed $40^{\circ} \mathrm{F}\left(4.4^{\circ} \mathrm{C}\right)$ where wa ter piping is at risk.

Finally, noncritical standalone buildings can be hibernated, but necessary measures should betaken, and the thermal environment should be maintained, when possible, to prevent significant damage to these buildings before they can be returned back to their normaloperation.

\section{References}

[1] American Society of Heating, Refrigerating and Air-Conditioning Engineers (ASHRAE), Thermal Environmental Conditions for Human Occupancy, ASHRAE Standard 55, Atlanta, GA: ASHRAE, 2017.
[2] ASHRAE, Design Considerations for Datacom Equipment Centers, ASHRAE Datacom Series Atlanta, GA: ASHRAE, 2005.

[3] NFPA 99. 2018. Health Care Facilities Code. NationalFire Protection Association.

[4] ASHRAE, "HVAC applications," ASHRAE Handbook, Atlanta, GA: ASHRAE, 2019.

[5] Guide for Resilient Thermal Energy Systems Design in Cold and Arctic Climates. 2021. Editor: AlexanderZhivov. ERDC.

[6] American Conference of Governmental Industrial Hygienists (ACGIH), Heat Stress and Strain: TLV(R) Physical Agents, 7th ed., Cincinnati, $\mathrm{OH}$ : ACGIH, 2017.

[7] National Institute for Occupational Safety and Health (NIOSH), Criteria for a Recommended Standard: Occupational Exposure to Heat and Hot Environments, DHHS (NIOSH) Publication Number 2016-106, Cincinnati, OH: U.S. Department of Health and Human Services, Centers for Disease Control and Prevention, National Institute for Occupa tional Sa fety and Health, 2016.

[8] American Conference of Governmental Industrial Hygienists (ACGIH), ColdStress: TLV(R) Physical Agents, $7^{\text {th }}$ ed. Cincinnati, OH: ACGIH, 2018.

[9] E. C. Winfield, R. J. Rader, A. M. Zhivov, T. A. Adams, A. Dyrelund, C. Fredeen, O. Gudmundsson, B. Goering, Best "Practices for HVAC, plumbing, and heat supply in arctic climates," ASHRAE Trans., vol. 127, Part 1,2021.

[10] Jeffrey R. Gordon. 1996. An Investigation into Freezing and Bursting Water Pipes in Residential Construction. Building Redsearch Council Publication.https://www.ideals.illinois.edu/handle/ 2142/54757

[11]K. C. Parsons, Thermal Comfort. In: Parsons KC (Editor), Human Thermal Environments: The effects of hot, moderate, and cold environments on human health, comfort, and performance, $2 \mathrm{~d}$ ed., London, UK: Taylor \& Francis, 2003, pp. 198-228.

[12]P. Wargocki and D. P. Wyon, “Ten questions concerning thermal and indoor air quality on the performance of office work and schoolwork." Building and Environment, vol. 112,pp. 359-366, 2017.

[13]ASHRAE, Energy Standard for Buildings Except Low-Rise Residential Buildings, ASHRAE Standard 90.1, Atlanta, GA: ASHRAE, 2004.

[14]B. K. Oberg, A. Urban, E. Leffel, J. Goebel, M. Perry, D. Vas, D. Broderson, R. Liesen, and A. Zhivov, "Thermal energy system resilience: thermal decay test (TDT) in cold/arctic climates, Part I: Data collection and protocol," $A S H R A E$ Trans., vol. 127, no. 1, 2021.

[15]R. Liesen, B. Morton, and B. Diggs-McGee, "Thermal energy system resilience: Thermal decay test (TDT) in cold/arctic climates, Part II modeling," ASHRAE Trans., vol. 127, no. 1,2021. 